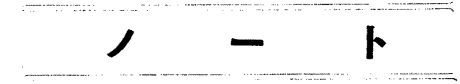

（三洪秼式会社高峰研究所）

\section{$\alpha$-ナフトキノンのポーラログラフ法 による定量}

(昭利 27 年 4 月 3 日受理)

丸㙳生

彷来キノン類の定量法としては，試籼を少量のアルコ ールに溶解し, 又別に 20cc のアルコールに, 20cc の 濃硫酸を泠却しつ」混合し, 其に $20 \mathrm{cc}$ の $10 \%$ 沃度力 リ溶液を加える・この液を前䛉試料溶液に加え，その際 遊離する沃度を遖ちに N/10 チ才硫酸ソーダ溶液で滴定 するいわゆる沃度法が用いられている。

しかるに著者はこれが定量法としてポーラログラフ法 を利用すれば，極めて簡易にしかも迅速に行い得る見通 しを得たので溢染としてベンゼン，エタノールの混合非 水溶液攻び $95 \%$ エノールを用いて行つた際の三三の 知見を郝告する。

まずベンゼン，エタノールの $1: 1$ の混合液を用い $\mathrm{N} / 10 \mathrm{LiCl}$ を電解颃として用いて還元した処第 1 困のよ

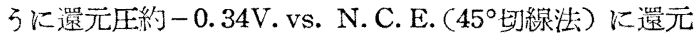

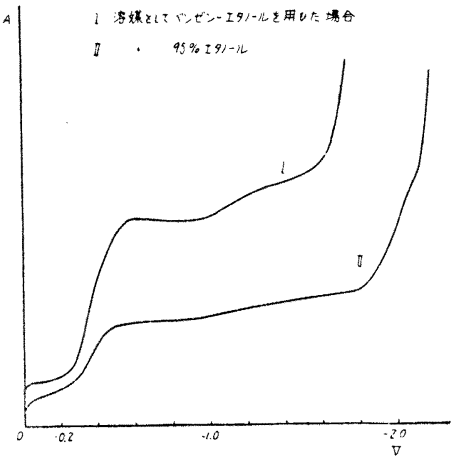

第 1 図

没をもつたポーラログラムが得られた。な技をの唯元波

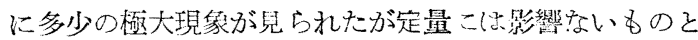
考えられる。次に溶媒として 95\% 五タノールを用いて

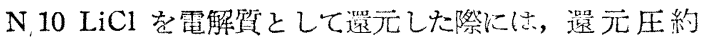
-0.31V.vs. N.C. E. に䢰元没をもつたポーラログフム が得られた.この際には極大現象は見られなかつた。

そこでその濃度と波高との関係を調べたところ 1〜10 $\times 10^{-4} \mathrm{~mol} / 1$ の間にいずれの場合も直線関係がある事 を確め,いずれの溶媒を用いた場合にす盉元圧濃度々波 高との関係に大した䊀ななく，定量の対象となる試料に 対してそれぞれ考志すればよいものと思う。

な扣三三の合成試料について定量した結果を示せば第
1 表のよろな結果得られ, 工策分析として適当なるのと 考えられる。

これらのキノン類のポーラログラフィー改び近時問題

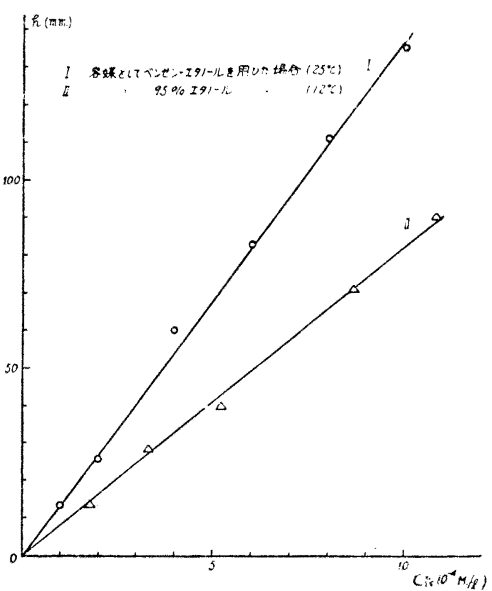

第 2 図

となつている無水フタール酸中の题量のナフトキノンの 定量に利用寸るには別途の考虑が必琹であるのでこれ らに関しては別に報告する予定でありここではキノン 第 1 表

溶媒としてベンゼンーェタノールを朋いた場合

\begin{tabular}{c|c|cc} 
& $\begin{array}{c}\text { 計 算 值 } \\
\left(\times 10^{-4} \mathbf{M} / 1\right)\end{array}$ & I & II \\
\hline 1 & 2.39 & 2.28 & 2.25 \\
2 & 1.99 & 2.00 & 2.15 \\
3 & 1.59 & 1.50 & 1.60
\end{tabular}

溶媒として 95\%エタノールを用いた場合

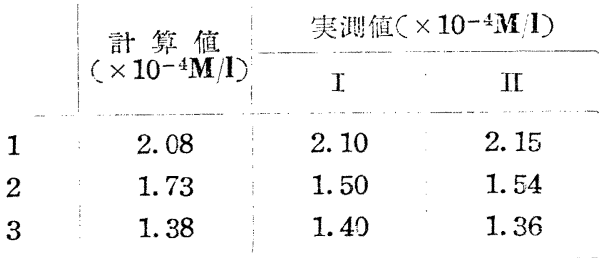

類の定量にポーロラグラフ法が利用可能である事实のみ

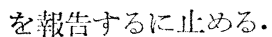

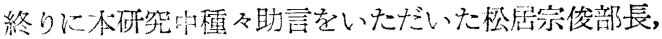
怕松不二夫課長に深謝すると共に，試籼を代与された東 亚ペイント株式会社の沢潤氏に愿く御礼申上げる。

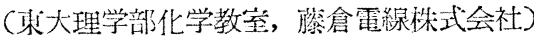

\section{1 オン交換樹脂による迅速分析の一例}

(硫酸金同中の硫酸基皮び硫酸銅一硫 酸混合溶液中の遊離硫酸の容量分析)

（昭和27年 4 月 15 日受理） 垣花秀武・八代健輔 